\title{
Thinking About the End Before You Start — Integrating Mine Closure Planning into Feasibility Studies and Environmental and Social Impact Assessment
}

\author{
S.J. Finucane URS Australia Pty Ltd, Australia
}

\begin{abstract}
It is widely recognized that mine closure planning should be an integral part of overall mine planning. Ideally, this process should commence in the earliest phases of feasibility assessments. Closure planning that is tailored to the needs of the project, and is commensurate with the level of feasibility study or other assessment being conducted at that time, can influence project decisions, trigger improvements in project design and provide rigor to costings. In some instances, early consideration of closure issues and costs may even prevent a company from proceeding with a project that would incur significant liabilities or would be unsustainable. For many projects, a mine closure plan is prepared when required for the site's environmental and social impact assessment and permitting process. All too frequently, this is the first time that closure requirements have been considered in the planning process.

Mine closure planning conducted during impact assessment tends to focus on the development of high-level closure objectives and strategies, but provides little information on how these will be implemented, and generally does not include a closure cost estimate. Consequently, there is little certainty about whether the proposed closure plan can be implemented effectively, and the stated outcomes can be achieved. The challenge for mine closure planning during feasibility studies and impact assessments is to provide sufficient certainty for proponents, regulators, shareholders and other stakeholders at a stage in the project life that is often characterized by degrees of uncertainty. There needs to be clear guidance on how closure objectives can be achieved within the broader project framework so as to facilitate effective decision making at all levels. However, inherent in closure planning should be sufficient flexibility and adaptive management to address, for example, changes in project designs and stakeholder requirements, operational constraints and other circumstances not evident during the planning process, technological advances and improvements in industry best practice. This paper discusses key considerations and presents suggestions for integration of mine closure planning into feasibility studies and environmental and social impact assessments.
\end{abstract}

\section{Introduction}

The need to initiate closure planning early in the life of a project is well documented and generally accepted by industry, government, non-government organizations (NGOs) and the wider community. There is also now general recognition that appropriate integration of mine closure planning into feasibility studies and environmental and social impact assessments (ESIAs) can influence project decisions, trigger improvements in project design and provide rigor to project costings. However, timing, focus and level of detail are highly variable.

Closure planning should be tailored to meet the needs of the project, and be commensurate with the level of feasibility study or other assessment being conducted at that time. There are many factors that need to be considered in integrating closure planning into feasibility studies and ESIAs, and guidelines on the contents and format of mine closure plans are readily available. These include:

- Guidelines produced by the International Council on Mining and Metals (ICMM) (see www.icmm.com).

- The mine closure and completion guidelines produced by the Department of Industry, Tourism and Resources (DITR) as part of Australia's Leading Practice Sustainable Development Program for the Mining Industry (DITR, 2006). 
- The Strategic Framework for Mine Closure produced by the Australian and New Zealand Minerals and Energy Council (ANZMEC) and Minerals Council of Australia (MCA) (ANZMEC and MCA, 2000).

Consequently, this paper does not attempt to address all of these considerations, but focuses on seven aspects, as follows:

- Considering options.

- Influencing project design and managing change.

- Incorporating sustainability.

- Assessing environmental and social risk of closure.

- Engaging with stakeholders.

- Planning for unexpected or unplanned closure.

- Estimating the cost of closure.

\section{Stages of closure planning}

The need for mine closure to be an integrated part of the complete project life cycle is well documented. The Mining, Minerals and Sustainable Development (MMSD) project recognizes that a closure plan should be established and integrated into the mine plan and management system at "the earliest opportunity" (MMSD, 2002), but what does this mean? For many projects, the first time that closure planning is considered in any detail is when demanded by the site's ESIA and permitting process. However, closure planning should commence during the exploration and feasibility phases at a low level of detail and increase in detail as project planning and development continues (Table 1).

During the exploration phase of a project, a company's objective is to determine whether there is sufficient resource to justify proceeding with development of a mine. With the focus on planning to start operations, there is usually little consideration of closure issues. Further, project budgets are usually tight at this stage of development and companies are all too aware that mineral exploration does not always result in the development of a mine, so there is often reluctance to incur expenditure on closure planning. However, certain activities such as the collection of baseline environmental data and targeted stakeholder engagement are beneficial. For example, early assessment of current land uses and ownership assists a company in determining the post-mining land use and planning for custodial transfer. This is particularly important for mines with a short project life as these negotiations can be lengthy, particularly where there are cultural sensitivities and language barriers. Early collection of baseline data not only provides information for the ESIA, but also facilitates development of environmental and social completion criteria. At this stage in the planning process, completion criteria should be outcome-based with the focus on what mine closure should achieve, not how to achieve this.

Once a company is confident that a viable mineral resource has been identified, it commences its feasibility assessments. A feasibility study examines the technical, economic, environmental and social practicality of a project and recommends the most effective design to meet the project objectives. It defines the basic factors that will determine the likely success of a project as well as the major risks to project success, and quantifies as many variables as possible in order to arrive at a potential value (DITR, 2006). Feasibility studies are staged to allow a progressive and considered assessment of the project, with an increasing level of detail and accuracy as the assessment moves from the scoping or concept study, to a pre-feasibility study, and then to a full feasibility study. The implications of mine closure should be considered at all levels of feasibility study to ensure that potential benefits are maximized and liabilities (including costs) are managed and minimized. 
Table 1 Closure planning phases

\begin{tabular}{|c|c|c|c|}
\hline Project Phase & Closure Design & Key Tasks & Documentation \\
\hline \multirow{5}{*}{$\begin{array}{l}\text { Exploration, } \\
\text { concept/scoping } \\
\text { study, pre- } \\
\text { feasibility study }\end{array}$} & \multirow[t]{5}{*}{$\begin{array}{l}\text { Low level of } \\
\text { certainty }\end{array}$} & $\begin{array}{l}\text { Identify broad sustainability objectives } \\
\text { for closure }\end{array}$ & \multirow{5}{*}{$\begin{array}{l}\text { Conceptual closure plan } \\
\text { including a closure cost } \\
\text { estimate to } \pm 30 \%\end{array}$} \\
\hline & & $\begin{array}{l}\text { Identify relevant environmental, } \\
\text { social, economic and governance } \\
\text { issues }\end{array}$ & \\
\hline & & $\begin{array}{l}\text { Conduct targeted stakeholder } \\
\text { engagement }\end{array}$ & \\
\hline & & Conduct a high-level risk assessment & \\
\hline & & $\begin{array}{l}\text { Prepare a high-level closure cost } \\
\text { estimate and establish a baseline for } \\
\text { financial provisioning }\end{array}$ & \\
\hline \multirow[t]{4}{*}{ Feasibility study } & \multirow[t]{4}{*}{$\begin{array}{l}\text { Moderate level } \\
\text { of certainty }\end{array}$} & $\begin{array}{l}\text { Review and revise outcomes of tasks } \\
\text { listed above }\end{array}$ & \multirow{4}{*}{$\begin{array}{l}\text { Preliminary closure plan } \\
\text { that includes a closure } \\
\text { cost estimate to } \pm 10 \%\end{array}$} \\
\hline & & $\begin{array}{l}\text { Ensure that closure tasks are fully } \\
\text { incorporated into project design and } \\
\text { operating plan }\end{array}$ & \\
\hline & & $\begin{array}{l}\text { Conduct wider stakeholder } \\
\text { engagement }\end{array}$ & \\
\hline & & $\begin{array}{l}\text { Identify priorities for research and } \\
\text { development }\end{array}$ & \\
\hline \multirow[t]{5}{*}{ Operation phase } & \multirow[t]{5}{*}{$\begin{array}{l}\text { High level of } \\
\text { certainty }\end{array}$} & $\begin{array}{l}\text { Revise closure objectives and plan as } \\
\text { more information becomes available }\end{array}$ & \multirow{5}{*}{$\begin{array}{l}\text { Updated closure plan and } \\
\text { closure cost estimate to } \\
\pm 10 \% \text { (refine as closure } \\
\text { nears) } \\
\text { Draft relinquishment and } \\
\text { sign-off plan }\end{array}$} \\
\hline & & Increase stakeholder engagement & \\
\hline & & Confirm process for closure approvals & \\
\hline & & $\begin{array}{l}\text { and lease relinquishment or custodial } \\
\text { transfer }\end{array}$ & \\
\hline & & Report & \\
\hline \multirow[t]{4}{*}{ Closure } & \multirow{4}{*}{$\begin{array}{l}\text { Highest level of } \\
\text { certainty }\end{array}$} & Implement final closure plan & Final closure plan \\
\hline & & $\begin{array}{l}\text { Monitor progress against closure } \\
\text { objectives and goals }\end{array}$ & \multirow[t]{3}{*}{$\begin{array}{l}\text { Final relinquishment and } \\
\text { sign-off plan }\end{array}$} \\
\hline & & Obtain sign-off from key stakeholders & \\
\hline & & Report & \\
\hline \multirow[t]{5}{*}{ Post-closure } & \multirow[t]{5}{*}{$\begin{array}{l}\text { Highest level of } \\
\text { certainty }\end{array}$} & $\begin{array}{l}\text { Validate closure objectives and } \\
\text { completion criteria }\end{array}$ & $\begin{array}{l}\text { Post-closure monitoring } \\
\text { document }\end{array}$ \\
\hline & & Monitor post-closure conditions & \multirow{4}{*}{$\begin{array}{l}\text { Relinquishment } \\
\text { document(s) }\end{array}$} \\
\hline & & $\begin{array}{l}\text { Implement remedial or contingency } \\
\text { works, if required }\end{array}$ & \\
\hline & & $\begin{array}{l}\text { Sign-off and tenement relinquishment } \\
\text { or custodial transfer }\end{array}$ & \\
\hline & & Report & \\
\hline
\end{tabular}

Source: Modified from Finucane et al. (2005)

Demonstrating the full feasibility of a project includes confirmation that the project has obtained all environmental and other approvals, or has at least made sufficient progress in this regard so that decisionmakers have confidence that these will be issued. This usually means that an ESIA is initiated during the definitive or bankable feasibility study. The ESIA process in many countries now includes a requirement for 
closure planning, with governments now realizing that they have the most direct responsibility for defining and ensuring comprehensive mine closure within the broader context of sustainability (Clark and Cook Clark, 2000). This has been recognized in Indonesia, where a decree by the Minister of Mines and Energy requires that a mine closure plan be submitted to the Director General of Mines at least one year prior to the cessation of mining operations. In Australia, the requirement for closure planning varies across the states and territories, but in general these have introduced increasingly stringent legislative and administrative requirements.

In Western Australia (WA), closure has historically been given little attention in ESIAs conducted under Part IV of the Environmental Protection Act 1986 (EP Act). For most large projects, a Part IV assessment is usually the primary approval obtained by a proponent, with a range of secondary approvals such as licensing under Part V of the EP Act, and approvals under the Mining Act 1978 and other legislation, also being required. Assessments conducted under Part IV in the late 1980s and any approval issued by the Minister for the Environment usually did not refer to closure plans, although the need for rehabilitation was acknowledged. By the late 1990s, a project assessed under Part IV of the EP Act usually included strategies and procedures for rehabilitation, and made a commitment to preparing closure and rehabilitation plans during the operational phase. For example, the public environmental review (PER) prepared for the St Ives Gold Mine in 1999 included rehabilitation procedures and provided a decision tree for the assessment of closure options for mine pits (Dames and Moore, 1999). The Ministerial approval for this project requires that a final decommissioning and rehabilitation plan be prepared at least two years prior to the anticipated date of closure.

More recently, it has become common practice to include a conceptual closure plan in the public ESIA document and for the Minister for the Environment to require finalization of the plan earlier in the project life. The 2005 PER produced for Gunson Resources Limited (Gunson) for the Coburn Mineral Sand Project (URS Australia Pty Ltd (URS), 2005) included a draft rehabilitation plan for progressive rehabilitation of the mine, and a conceptual closure plan addressing the final decommissioning, closure and post-closure activities. The Ministerial approval for this project requires that a preliminary closure plan be prepared prior to ground-disturbing activities, and that a final closure plan be prepared at least three years prior to the anticipated date of closure. The Ministerial approval for a proposal by Robe River Mining Company Pty Ltd (Robe) to develop the Mesa A/Warramboo Iron Ore Project also requires early development of a closure plan, with a mine closure rehabilitation plan required prior to the commencement of productive mining.

This evolution in closure planning requirements is also apparent in the environmental assessments of mining projects conducted by the WA Department of Industry and Resources (DoIR). Guidelines produced in the late 1990s by the department did not refer specifically to the need for closure planning, but required an outline of rehabilitation procedures and that a commitment be made to undertake progressive and final rehabilitation (Department of Minerals and Energy Western Australia, 1998). When these guidelines were updated in 2006, they included a new requirement for Mining Proposals to include a preliminary mine closure plan based on a site-specific set of completion criteria (DoIR, 2006). The DoIR requires that an environmental bond be lodged, but currently there is no requirement for closure costings to be included in the preliminary closure plan provided as part of the Mining Proposal. In comparison, the Northern Territory Department of Primary Industry, Fisheries and Mines (DPIFM) requires that the mining management plan (MMP) prepared to support an application for authorization of mining activities includes both closure planning and costings (DPIFM, 2008).

Closure planning by some proponents, particularly smaller companies, is often driven primarily by a need to meet regulatory requirements. A broad review of legal frameworks conducted by ICMM (2006a) indicated that, in general, legislation and regulation often lagged behind the practice of industry leaders. These companies set their own standards, which often exceed regulatory requirements. A number of organizations responsible for financing mining projects also define requirements for mine closure planning. For example, the European Investment Bank and the International Finance Corporation both require that a mine closure plan be developed for all mining projects they support.

Despite the drive by proponents, governments, financial institutions and other stakeholders to integrate closure planning into ESIA, a brief review of recent ESIAs published in WA indicates that the level of detail provided in these documents is highly variable and ranges from closure strategies (such as that produced for 
the Mesa A/Warramboo Project) to detailed, albeit conceptual, closure plans (such as those produced for the Coburn Mineral Sand Project). This is clearly not an Australia-specific issue as an international review of mine closure frameworks by Clark and Cook Clark (2000) also found that "regardless of the approach or the requirements... rehabilitation, reclamation and mine closure plans vary greatly among and within individual countries".

\section{Integrating closure planning into feasibility studies and EIAs}

As indicated in Section 1, this paper does not attempt to list all of the factors that should be considered in integrating closure planning into feasibility, but outlines seven key factors, as described below.

\subsection{Considering options}

Feasibility studies include consideration of technical, operational and other options relevant to the design and operation of a project. Consequently, it is recommended that a study of closure options also be conducted at this time to ensure that the feasibility of all potential outcomes has been assessed.

Closure planning early in the life of a project is characterized by uncertainty, though the degree to which this affects projects varies. It is unrealistic to expect that a company would have "all of the answers" at the beginning of a project, but what does the organization need to do to demonstrate sufficient knowledge and confidence that proposed outcomes can be achieved?

In determining how to respond to this question in relation to its proposal to develop the Coburn Mineral Sand Project in the Shark Bay region of WA, Gunson conducted consultation with key stakeholders during the early stages of its ESIA process. During this consultation, concerns were raised by the Environmental Protection Authority (EPA) about the feasibility and likely effectiveness of rehabilitation at Coburn. It was recognized that there was limited experience in mine site rehabilitation in the Shark Bay region, and that site conditions and other factors (such as the site's windy conditions, irregular rainfall, high evaporation rates and slow-growing vegetation) would present significant challenges to the rehabilitation programme. Therefore, Gunson commissioned URS to undertake a rehabilitation benchmarking study (RBS) to determine whether successful rehabilitation was possible at Coburn. This was a challenging request as there are no other mineral sands mines operating in the region or operating elsewhere under exactly the same conditions, so the RBS examined ten sites in the region as well as mineral sands mines in Queensland and South Africa.

The RBS identified a range of factors that have the potential to affect the rehabilitation success of the Coburn Project (Finucane et al., 2006), which became integral to the design of the draft rehabilitation plan, draft closure plan and other management plans included in the PER prepared for the project (URS, 2005). Following the EPA's assessment of the proposal (which included an independent technical review in relation to soil management for rehabilitation), the project was approved by the Minister for the Environment with the approval focusing strongly on the rehabilitation aspects of the project. Field methodologies will be evaluated during project operations, with the findings being used to improve the project rehabilitation and closure plans.

One of the key concerns at the ESIA stage is uncertainty about specific closure technologies. Consequently, technical review or verification may need to be conducted as part of an ESIA or feasibility study to provide sufficient confidence for internal and external decision-makers. An example of this is the recent assessment of Robe's proposal to develop the Mesa A/Warramboo Iron Ore Project in WA's Pilbara region. The proposal was assessed by the EPA as a PER, which included a closure strategy for the project (Sinclair Knight Merz, 2005). Part of Robe's strategy was to establish a Mining Exclusion Zone (MEZ) which comprised the "rim" of the mesa to be retained after mining to conserve landscape and Aboriginal heritage values associated with Mesa A.

During its assessment of the Mesa A/Warramboo proposal, the EPA acknowledged Robe's proposed measures for closure planning and rehabilitation, but considered that the proposal could not be managed to meet the EPA's objective in relation to landforms, mine closure and rehabilitation. One of the EPA's key concerns in this regard related to the long-term structural stability of the mesa landform following the cessation of mining (EPA, 2007a), with the possibility of collapse or slumping over time resulting in degradation of landscape and Aboriginal heritage values (EPA, 2007b). 
Robe appealed the EPA's report and recommendations on the project (EPA, 2007a), and subsequently provided additional information to the Minister for the Environment, including an independent geotechnical assessment which concluded that the MEZ would be stable after mine closure. The Minister then resubmitted the project and extra information back to the EPA for reconsideration. Following consideration of the additional information, the EPA concluded that the proposal could be managed to meet their environmental objectives provided that a number of conditions were fulfilled, including the implementation of a mine closure and rehabilitation plan (EPA, 2007b).

\subsection{Influencing project design and managing change}

The ability of closure planning to influence project decisions and trigger improvements in project design does not end with an assessment of closure options. Projects that are still in the planning phase have maximum freedom for these opportunities, whereas mines that are in the middle of their operating life present fewer opportunities. Mines that are close to the end of their economic life have limited options available to them. If planning is delayed, it may affect which mine closure objectives can be met (MMSD, 2002).

Site closure considerations influence many parts of a project, including such simple aspects as the site layout. When site layouts are designed, importance is placed on such factors as minimizing haulage distances and reducing the need for cut and fill earthworks. Consequently, waste rock dumps are usually located as close as possible to the pit or underground workings from which the material is to be sourced. This may mean that the waste dump may be located on more than one tenement. If the waste dump can be rehabilitated ahead of the cessation of mining, the company may be keen to relinquish the tenement on which the rehabilitated landform is located if it is not required for other project purposes. However, tenement relinquishment and retirement of environmental bonds may be held up where project components cross tenement boundaries, with additional expenditure likely to be incurred to maintain possession of the tenement. Where rehabilitation and closure of a waste dump or other site component are likely to occur ahead of other parts of the project, it is preferable to locate these on one or a few tenements that can be relinquished ahead of final site closure.

Other mine closure requirements can also affect site layout designs. For example, if it is proposed that subgrade ore which is not economical to process (and is, in effect, mineralized waste rock) will be used to cap a tailings storage facility (TSF), it is logical that this material be stored adjacent to the TSF rather than as part of a waste rock dump. If, however, this is not captured in the mine closure plan and the operational plan, then a company may find that the mineralized waste stockpile or the waste rock dump is located some distance from the TSF, and that it is double-handling this material at closure. It is also possible that commodity prices will change during the life of a project, and that what was previously considered to be sub-grade mineralized waste becomes economic to process. If the company decides to process the material instead of retaining it for closure purposes, it will need to find another source of capping material. This will trigger a change in the closure plan, and the potential for this to occur needs to be recognized in the plan from the start.

On occasion, closure planning considerations will trigger more significant changes in the design of a project, and it is important to ensure that site closure is planned in a way that guides the outcome without constraining innovation. As indicated in Section 3.1, it is unrealistic to expect that a company would have "all of the answers" at the beginning of a project and it is likely that research and development will be required to progress technical and other aspects of a closure plan. Further, it is possible that new technologies will be developed, and these will trigger significant redirection in a company's approach to mine closure. For example, improvements in the technology of evaporative covers for gold heap leach facilities in Nevada since the 1980s have seen a change in the approach to closing these sites that would not have been envisaged when many of these sites commenced operations (MMSD, 2002).

A closure plan that does not allow for the possibility for innovation and change will miss opportunities to improve outcomes and reduce costs. This does not mean that a company should be allowed so much freedom and scope for change that internal and external stakeholders are constantly unsure of what will be done to close the mine successfully, but there is a need for sufficient flexibility to incorporate new technologies and respond to changing circumstances that improve closure methodologies and outcomes, and alter closure costs. 
Changes in closure plans can also be triggered as a result of changes in government policies and plans, and other factors such as political change. Changing community needs can also modify a company's approach to mine closure. Having been a major employer in East Kalimantan for more than a decade, PT Kendilo Coal Indonesia (a subsidiary of BHP Billiton) was committed to leaving the community with a lasting positive legacy following closure of the Petangis mine site. A key component of closure planning by the company was consultation with community stakeholders that included discussion about how the site could be of use to the local villages following the cessation of mining. As a result of this consultation, it was decided that a tourism facility would be developed that included lakes and trees where the mine pits had been. In addition, an innovative joint venture was implemented once mining had been completed that allowed operations to continue for an additional year, which enabled the gradual downsizing of the Petangis workforce. This comprised the purchase of raw coal from a small neighboring mine, processing the coal through the Kendilo wash-plant and marketing it through BHP Billiton's global sales network. Although the Indonesian Government had issued technical directives on site rehabilitation, higher standards were required to meet community aspirations and company requirements (BHP Billiton, 2006).

A process to manage change should be clearly stated in the closure plan and flexibility should be an integral part of completion criteria to ensure that it is clear to regulators, NGOs and other stakeholders that not only is change expected, but that the company is positioned to respond so that maximum benefit is obtained and adverse impacts are mitigated or minimized.

\subsection{Incorporating sustainability}

An integrated approach to closure plays a fundamental role in creating value from both environmental and social perspectives. Consequently, integrating closure into project planning in a way that takes environmental and social considerations into account from project initiation and throughout its life cycle is an opportunity to leverage the value created by a mine (ICMM, 2006a). If integrated closure planning starts too late in a mine's life cycle, then it could be difficult to ensure long-term environmental, community and economic sustainability (MMSD, 2002).

A study by ICMM (2006a) investigated how well social and environmental aspects were integrated into the closure planning process, and found that the newer closure issues such as biodiversity, community needs and climate change issues were not addressed as well as the more traditional considerations such as revegetation and landform stability. Companies need to build these aspects into their completion criteria, and widen their focus to include the self-sustainability of the community and region in which the mine is located. At the early stages of closure planning, these criteria need to focus on outcomes rather than being too specific about how these would be achieved. As closure planning progresses, they are refined and become more precise.

ICMM (2006a) found that the category of stakeholders most commonly included in the closure planning process is usually local government, which clearly demonstrates the importance of linking mine closure planning with local economic development plans. Linkages with the local planning framework ensure that post-mining land uses are compatible with surrounding development initiatives and provide a context against which a mine's investments in human capital and infrastructure can meet local and regional development needs, and create a mechanism for economic growth following the cessation of mining (Limpitlaw, 2004).

One way to ensure that the full range of sustainability issues is adequately addressed in closure plans is to have multidisciplinary teams develop the plans. Feasibility studies and ESIAs are conducted using multidisciplinary teams working together to optimize the design and operation of a mine, and companies should take advantage of these teams being in place to establish closure objectives as part of the closure planning process and train them to "think about the end before they start".

ICMM (2006a) indicates that the discipline with the greatest level of influence on closure planning is environmental, followed by engineering, with more attention required on social and community needs. This suggests that an increased use of social and community expertise (including expertise in human resources) is required to ensure the development of comprehensive closure plans. It also suggests that there continues to be a need to integrate social impact assessments into mine planning, and to ensure that a social mining plan is part of the overall mine development (Clarke and Cook Clark, 2000). 


\subsection{Assessing environmental and social risk of closure}

Feasibility studies and ESIAs usually assess the environmental and social risks of constructing and operating projects, but do not always consider the risk of closing a project, presumably because project closure is seen as a mitigation measure in itself. However, the actual process of mine closure can result in a range of environmental, social and economic impacts, as discussed below.

For communities that have become dependent on a mining project for direct and indirect income, the provision of water and power, and other assistance, mine closure can have a devastating impact. This is exacerbated in developing countries where there may be little alternative economic activity available, and local government and communities lack the skills and resources to provide suitable alternatives (Sheldon et al., 2002). Pershke and Elliott (2007) recommend the use of a high level community vulnerability and resilience assessment in the early stages of a mine's life to assist organizations in focusing their community programmes in ways that will assist in mitigating the socio-economic impacts associated with closure.

A key risk for mine closure is the long-term management of permanent engineered facilities such as TSFs, waste dumps and surface drainage features such as spillways and diversion channels. Consequently, it is important to consider the long-term risk of facility failure. Feasibility studies and ESIAs usually define the design criteria to be applied to a project based on its operational life. For example, surface drainage design for a mine with a relatively short operating life may use a 100 -year annual recurrence interval for precipitation, which implies a relatively low risk of exceedence during a short project life. However, some components of the project (such as a TSF) may need to be stable for a very long period, comprising decades or centuries. Consequently, the long-term design criteria need to reflect the conditions likely to be experienced in the much longer term, and to take into consideration factors such as climate change (MMSD, 2002).

The risk of the decommissioning and closure activities themselves resulting in environmental impacts should also be considered. For example, there is a risk that reagents remaining at a site will leak or spill during removal of the processing plant, which could result in soil and water contamination. Further, there is a risk of on-going pollution if the underdrainage and seepage recovery system associated with a TSF is decommissioned before any groundwater plume has been remediated.

Risk assessments conducted during feasibility studies and EIAs need to address the environmental, social and economic risks of site closure, and the outcomes of these assessments should be incorporated in the site's risk register. As the register is reviewed and updated during the life of the project, the risk profile on which the closure plan is based should be modified.

Risk assessments usually quantify the likelihood and consequence of a particular event or circumstance, and the advantage of a risk-based approach to closure planning lies in the quantification of subjective factors and the analysis of uncertainty in relation to both design performance and cost (ANZMEC and MCA, 2000). However, this can be difficult during the early stages of project planning when little "hard data" on closure are available. Pershke and Elliott (2007) report that while most organizations incorporate risk assessment processes into their day-to-day operations, there is often confusion in how to apply these processes to closure issues. These authors found that risk assessment methods are often developed with safety in mind, so it can be difficult to apply them to closure risks because the likelihood scales are often different. Organizations also had difficulty in applying the right level of detail to a risk assessment and closure risks were often poorly described. This, in turn, resulted in an inappropriate risk ranking and failure to identify suitable risk mitigation measures. Further, the boundary of the risk assessment was often poorly defined so the key closure risks were not identified while issues not wholly relevant to mine closure were incorporated.

Where consideration of closure risks within a traditional risk assessment methodology is problematic, proponents should consider alternative tools such as strategic environmental assessment (SEA) as a tool for the assessment of closure risks and issues, including those of various project options.

\subsection{Engaging with stakeholders}

A mine closure plan provides a view of the potential future for a community's economic and social life (MMSD, 2002). Consequently, it is important that this view be shared and developed in consultation with relevant stakeholders. 
ANZMEC and MCA (2000) states that the objective of stakeholder involvement is "to enable all stakeholders to have their interests considered during the mine closure process". However, MMSD (2002) notes that while "it is ideal to work with communities to develop mine closure plans, it rarely happens that way". Typically, there is little or no consultation with stakeholders during feasibility studies, with the ESIA process providing the first opportunity to engage with stakeholders in relation to project closure planning.

The post-mining land use is a critical driver for closure planning, and local communities often have different ideas to proponents about the possibilities that a former mine site could offer. Consequently, post-mining land uses are far more likely to be supported by local communities in the long-term if they have been an integral component of the decision-making process (ICMM, 2006a). Therefore, it is recommended that stakeholder engagement commences from the exploration and conceptual stages of a project, particularly in relation to the post-mining land use. This needs to include engagement with government to ensure compatibility with current and future land use plans proposed for the region. This prevents situations such as that faced by one mining company when it proposed ecotourism as its post-mining land use, only to discover government plans for a manufacturing node in the area (Limpitlaw, 2004).

Stakeholder engagement is particularly important if companies are planning to transfer project assets and infrastructure to a community. Companies and communities recognize the benefits of such a transfer, but simply handing over assets such as power stations and other project components rarely works unless the community actually wants them, and is positioned to sustain their use. Significant time and resources are required to train community members and develop the systems required to operate and maintain the equipment after hand-over. This needs to commence early in the project life, particularly if the operational phase of a project is short. Custodial transfer can be a complex and lengthy process, particularly where a number of parties are involved.

From an industry perspective, one of the reasons for poor closure performance is uncertainty about the social requirements for closure. The stage at which stakeholders are engaged in the closure planning process and their level of involvement can have an impact on the robustness of the engagement and the way in which this influences the decision-making process (ICMM, 2006a). However, it is important that community and individual expectations are not raised to unrealistic levels, and that any excessive community focus on issues such as compensation are managed carefully (Limpitlaw, 2004).

\subsection{Planning for unexpected or unplanned closure}

In an ideal world, mines would only close in an orderly, pre-planned manner when their mineral resources were exhausted or at another pre-determined time. Of course, in reality mines can close unexpectedly for a range of reasons including changes in commodity prices, operational difficulties, problems with ore grades, environmental issues, political instability, community concerns and other factors. At the time of temporary closure, it can be very difficult to predict the length of time that a site will remain in this state, so it is difficult to make contingency plans (MMSD, 2002). Many such temporary closures result ultimately in such mines being abandoned (Clarke and Cook Clark, 2000). Laurence (2002, as cited in DITR, 2006) indicates that nearly $70 \%$ of the mines that have closed in Australia over the past 25 years experienced unexpected or unplanned closures for reasons other than exhaustion or depletion of reserves.

The recent gas shortage in WA has demonstrated how mines can close unexpectedly due to factors beyond their control. On 3 June 2008, a pipeline rupture and fire occurred at Apache Energy's Varanus Island gas plant off WA's Pilbara coast. At the time that this paper was prepared, investigations into the incident were ongoing and the cause had not been published. However, the effect of the incident was felt immediately, with a $30 \%$ reduction in WA's gas supplies.

Most of the gas delivered through the Varanus plant is supplied to industrial customers. As a result of the pipeline incident and subsequent gas shortages, numerous companies reduced or shut down their mining and mineral processing operations for a period of time. These included Newcrest Mining Australia, Minara Resources, Iluka Resources Limited and Barrick Gold (who closed the mill at the Plutonic mine for a period of time to conserve diesel-fuelled power).

A survey by the Chamber of Minerals and Energy Western Australia (CMEWA) found that more than 25\% of its production members did not have the capacity to switch from gas to diesel power. In these instances, 
mineral processing operations were wound down or suspended entirely (CMEWA, 2008). A number of companies were able to switch to diesel-powered electricity, but it has been reported that since the Varanus pipeline incident demand for diesel has increased by $40 \%$ (Gosch, 2008). For those mines able to locate alternative sources of fuel, these came at significant cost. For example, on 16 June 2008, Norton Gold Fields (the operator of the Paddington gold mine north of Kalgoorlie) announced that its energy costs would increase by $\mathrm{A} \$ 1.6$ million a month for a three month period as a result of the Varanus fire (Norton Gold Fields, 2008). For those sites able to source alternative energy supplies, the increased cost of fuel may make it difficult to sustain production, and they may be forced into temporary closure if the energy situation continues.

In addition to the direct impacts resulting from the loss of energy, the gas shortage could result in indirect impacts on mines where companies that supply goods and services to the resources sector are also affected (CMEWA, 2008). Industrial gas suppliers and reagent producers have been affected, and Wesfarmers suspended production at its CSBP ammonia and cyanide plants. In addition, the availability and haulage costs of diesel are likely to be affected, which may create secondary power outage issues (G. Hawkins, as quoted by Loney, 2008).

At the time that this paper was prepared, it was too early to predict the full impact of the gas crisis on the WA and Australian mining industry. However, the CMEWA has warned that "if gas shortage continues, a cascade of adverse consequence will occur", with nearly half of the surveyed companies reporting that, while they are not affected in the short term, there will be consequences in the longer term (CMEWA, 2008). If the gas crisis becomes prolonged, some companies may find that they are unable to tolerate the reduced cashflow and other issues that accompany temporary closure, and that they may not be in a position to restart their project(s). Consequently, a temporary closure may become a permanent closure. Those companies that have included provision for unplanned closure in their mine closure planning process will be better placed, practically and financially, to ameliorate the negative effects of unexpected or unplanned closure.

\subsection{Estimating the cost of closure}

One purpose of a mine closure plan is to obtain a cost estimate of closure so that financial surety can be established, and to ensure appropriate level of provisioning for rehabilitation and closure. It is recognized that it is better for companies to make advances towards closure during the life of the mine than to incur large expenditures on rehabilitation and closure when they are no longer receiving an income from the project (MMSD, 2002). However, it is also important to incorporate closure cost estimates into a feasibility study's economic analysis as, in some instances, closure costs may even prevent a project from going ahead if the cost of closure is more than the potential financial gains from the project.

It is important that the closure cost estimate be based on an actual closure design and that the closure plan itself is sufficiently advanced that it provides a fairly accurate basis to ensure that estimates, and therefore bonds and other financial sureties, are not over or under estimated. As changes to the closure plan occur, these should trigger a review of the closure cost estimate. It is also important that the schedule of rates and charges (including exchange rates) be documented, along with any assumptions made in preparing the cost estimate. This will make it easier to identify what might have changed when it is time to update the costs. If assumptions used in defining a cost are not reviewed, then any errors and discrepancies can be carried through from one version of a plan to the next (Pershke and Elliott, 2007).

Closure cost estimates need to take into account the uncertainty associated with the costs and conditions that may be encountered during closure execution. This is particularly relevant to demolition costs, which are often estimated using "rule of thumb" methods. However, this uncertainty can be reduced if a quote is obtained from a demolition contractor. Obtaining a quote also provides a robust and auditable justification of the cost (Pershke and Elliott, 2007).

Closure cost estimates usually focus on the activities associated with the decommissioning and rehabilitation of a site, but do not always factor in the costs associated with such aspects as project management, postclosure monitoring and contingencies in the event that rehabilitation or remediation fail and need to be redone. Other costs, such as cleaning a plant once processing has finished and before demolition occurs, are also often overlooked. These can significantly increase the cost of mine closure. 
Significant increases in closure costs for the Mt Leyshon gold mine in Queensland have been experienced by Newmont Australia. In 1997, the projected closure provision for the site (not including the waste rock dumps) was A $\$ 3$ million, but this had increased to A $\$ 8.7$ million by 2000 . Ramsey (2003) reports that the expected expenditure in 2004 was around A $\$ 12$ million, with the increase in costs due primarily to the need for extra cover material for the TSF, an increase in post-closure costs, and what was termed "hidden extras".

The method of calculating closure costs should be given careful thought. Calculations based on the ultimate footprint of the mine site and the use of blanket formulae do not adequately consider site-specific factors that affect the cost of closure (ICMM, 2006b). MMSD (2002) notes that some companies accrue funds for mine closure based on a production rate (such as $\$$ per ounce of gold), which also may not adequately address the specific closure requirements of a site. Probabilistic and range analysis techniques are being used by a number of organizations in estimating closure costs, and enable uncertainties associated with site-specific costs and conditions to be incorporated into the closure cost estimate (Pershke and Elliott, 2007).

In developing a closure cost estimate, consideration should be given to the time that closure will take to implement. It is not uncommon for closure plans to assume that all closure activities will occur concurrently, or at least in a continuous sequence. However, reasonable time periods can occur between initial and final closure activities where, for example, a site must wait for a TSF to dry out before being able to cap and complete rehabilitation of the facility. If the workforce used for the final closure activities requires on-site accommodation (as is usually the case for remote sites), then there will also be a delay in closing and rehabilitating this infrastructure, and additional costs incurred in maintaining it until after it is used during the final closure phase.

There should also be allowance for the cost of unexpected closure, particularly if this occurs early in the life of the project when projects are often most vulnerable and most of the cash flow is directed to debt repayment. Unexpected closure may require that a closure plan needs to be implemented before adequate funds have accrued.

\section{Conclusion}

When implemented soundly, the process of integrating closure planning into feasibility studies and EIA provides a strong foundation for project development. However, it is critical that closure planning be a central part of the overall project planning process. Even sophisticated closure planning, if sidelined when managers are making decisions about the rest of a project, is less likely to achieve the desired outcomes and benefits. To be effective, closure planning needs to be integrated into business planning right from the start, and companies need to ensure that changes in mine planning and closure planning are sufficiently integrated so that changes in one cause changes to be reflected in the other (ICMM, 2006a). This is much easier to achieve if integrated closure planning is part of a company's culture from its inception.

\section{Acknowledgements}

The author would like to thank Scott Mernitz, Kate Philp and Diana Oates from URS Australia Pty Ltd for their assistance in the preparation of this paper.

\section{References}

Australian and New Zealand Minerals and Energy Council and Minerals Council of Australia (2000) Strategic Framework for Mine Closure. Australian and New Zealand Minerals and Energy Council and Minerals Council of Australia, $22 \mathrm{p}$.

BHP Billiton (2006) Environment case study: Petangis mine closure and rehabilitation program receives environmental awards. BHP Billiton Sustainability Report 2006 available at http://www.bhpbilliton.com/bb/investorsMedia/ reports/2006/2006BhpBillitonSustainabilityReport.jsp.

Chamber of Minerals and Energy Western Australia (2008) WA Resources Sector Suffering Major Dislocation in Gas Outage. Media release no. CME 15-08. 12 June 2008, 1 p.

Clarke, A.L. and Cook Clark, J. (2000) An international overview of legal frameworks for mine closure. Mine Closure and Sustainable Development Workshop, Washington DC. 1-3 March 2000, 25 p.

Dames and Moore (1999) Public Environmental Review. Gold Mine Developments on Lake Lefroy. Prepared for St Ives Gold. September 1999. 
Department of Industry and Resources (2006) Guidelines for Mining Proposals in Western Australia. February 2006. Government of Western Australia, 74 p.

Department of Industry, Tourism and Resources (2006) Mine Closure and Completion. Commonwealth Government of Australia, $63 \mathrm{p}$.

Department of Minerals and Energy Western Australia (1998) Guidelines to Help You Get Environmental Approval for Mining Projects in Western Australia. March 1998. Government of Western Australia, 74 p.

Department of Primary Industry, Fisheries and Mines (2008) Mining Management Plan (MMP) - The Basics. Advisory note available at www.nt.gov.au/dpifm/Minerals_Energy/Content/File/Forms_Guidelines/, 2 p.

Environmental Protection Authority (2007a) Mesa A/Warramboo Iron Ore Project. Report and recommendations of the Environmental Protection Authority. Bulletin 1251, March 2007.

Environmental Protection Authority (2007b) Mesa A/Warramboo Iron Ore Project. Report and recommendations of the Environmental Protection Authority. Direction from the Minister for the Environment under section 43 of the Environmental Protection Act 1986. Bulletin 1264, September 2007.

Finucane, S., Reichardt, M. and Elliott, P. (2005) Key environmental and socio-economic considerations in planning for sustainable mine closure. Mining for Sustainable Development: Extracting More Benefit for Africa. Chamber of Mines of South Africa. November 2005, 12 p.

Finucane, S., Hardman, B. and Harley, D. (2006) Planning for rehabilitation and closure of the Coburn mineral sand mine at Shark Bay, Western Australia. Mine Closure 2006. Proceedings of the First International Seminar on Mine Closure. A. Fourie and M. Tibbett (eds), Perth, Western Australia. September 2006, pp. 359-370.

Gosch, E. (2008) Bang goes the boom. The Australian. 19 June 2008, p. 13.

International Council on Mining and Metals (2006a) Integrated Closure Planning. September 2006, 6 p.

International Council on Mining and Metals (2006b) Guidance Paper: Financial Assurance for Mine Closure and Reclamation, March 2006, 8 p.

Limpitlaw, D. (2004) Mine closure as a framework for sustainable development. Sustainable Development Practices on Mine Sites - Tools and Techniques. University of the Witwatersrand, 8-10 March 2004, pp. 1-11.

Loney, G. (2008) Miner shuts mill. Kalgoorlie Miner, 19 June 2008, p. 1.

Mining, Minerals and Sustainable Development (2002) Appendix B: Mine closure working paper. Mining for the Future. International Institute for Environment and Development and World Business Council for Sustainable Development. April 2002, 22 p.

Norton Gold Fields Limited (2008) Impact of Interim Power Supply Arrangements on Paddington. ASX/Media announcement. 16 June 2008, 1 p.

Pershke, D. and Elliott, P. (2007) Sustainable mine closure planning: moving towards best practice - experiences and observations. SD07: A Climate for Change. Minerals Council of Australia, 7 p.

Ramsey, K. (2003) Project managing a mine closure - Mt Leyshon case study. Sustainable Mine Closure. Australian Centre for Mining Environmental Research, Queensland. October 2003.

Sheldon, C.G., Strongman, J.E. and Weber-Fahr, M. (2002) It's Not Over When It's Over: Mine Closure Around the World. World Bank and International Finance Corporation.

Sinclair Knight Merz Pty Ltd (2005) Mesa A Closure Statement. December 2005.

URS Australia Pty Ltd (2005) Coburn Mineral Sand Project Public Environmental Review. Prepared for Gunson Resources Limited, July 2005. 